\title{
レチノイドによる自己免疫疾患の治療
}

深澤弘志*1, 影近弘之*2,*3, 首藤 紘一*3

\section{Retinoid Therapy for Autoimmune Diseases}

\author{
Hiroshi FuKASAwA*1, Hiroyuki KAGECHIKA ${ }^{* 2, * 3}$ and Koichi SHUdO*3 \\ ${ }^{*}$ Department of Drug Development, Institute of Medicinal and Molecular Design, Inc. \\ ${ }^{*}$ School of Biomedical Science, Tokyo Medical and Dental University \\ ${ }^{*}$ Research Foundation Itsuu Laboratory
}

(Received May 8, 2006)

summary

Retinoid is a collective term for compounds which bind to and activate retinoic acid receptors ( $\mathrm{RAR} \alpha, \beta, \gamma$ and $\operatorname{RXR} \alpha, \beta, \gamma)$, members of nuclear hormone receptor superfamily. The most important endogeneous retinoid is alltrans-retinoic acid (ATRA) which is an $\operatorname{RAR} \alpha, \beta$ and $\gamma$ ligand. ATRA and its mimics have been in clinical use for treatment of acute promyelocytic leukemia (APL) and some skin diseases. Many synthetic retinoids have been developed and attempts to improve their medicinal properties have been made. Among them, tamibarotene (Am80) is an RAR $\alpha-$ and RAR $\beta$ - specific (but RAR $\gamma$ - and RXRs-nonbinding) synthetic retinoid that is effective in the treatment of psoriasis patients and relapsed APL. Experimentally, this compound is also active in animal models of rheumatoid arthritis and experimental autoimmune encephalomyelitis. On this background, possible application of retinoids for the treatment of autoimmune diseases was discussed. In particular, Th1 dominant autoimmune diseases may be the targets of the retinoids.

Key words — Retinoid; Tamibarotene; Psoriasis; Autoimmune Disease; Type1 Helper T cells

抄録

レチノイドとは，核内ホルモン受容体スーパーファミリーに属するレチノイン酸受容体（RAR $\alpha, \beta$ 小よび $\gamma$ と $\operatorname{RXR} \alpha, \beta$, および $\gamma)$ に結合し, これらを活性化する化合物の総称である. 内在性に存在する最も重要な生体内レ チノイドは, all-trans-レチノイン酸（ATRA）であり，これはRAR $\alpha, \beta, \gamma$ を別なく活性化する. ATRAおよび その類似化合物が急性前骨髄球性白血病（APL）や皮膚疾患の治療に用いられている一方で, 数多くの合成レチ～ イドが合成され，医薬としての性状を改善する試みも行われている，中でも，タミバロテン（Am80）は，RAR $\alpha$, $\beta$ のみを活性化し， RAR $\gamma$ やRXRs には結合しない特徵的な合成レチノイドである. Am 80 は, 乾癬と再発 APL の治療において有効性が確認されていることに加え，コラーゲン誘導関節炎モデルや実験的自己免疫性脳炎 (EAE) においてもその効果を示す。レチノイドは, 特に Th1 優勢な自己免疫疾患に有効ではないかと考えられる.

\section{レチノイドとは}

レチノイド (retinoid) とは, ビタミンA の活性 本体である all-trans-retinoic acid（ATRA，以下， レチノイン酸；図 1) とそれと同等の活性を示す化 合物群の総称である。 より正確には, Spornによっ て定義されたように，核内に存在するレチノイン酸 の特異的受容体 retinoic acid receptor (RAR) のレ チノイン酸結合部位に結合する化合物である1).

\footnotetext{
$*_{1}$ 侏医薬分子設計研究所創薬事業部

$*_{2}$ 東京医科歯科大学大学院疾患生命科学研究部

*3(財) 乙卯研究所
}

RAR をレチノイン酸のように活性化する化合物 （アゴニスト）やその活性を阻害する化合物（アン タゴニスト）がすでに多数，化学合成されており， それらも含めて本稿の対象とするレチノイドである.

RAR と相同の核内受容体である RXR (retinoid-X receptor, 後述) に結合する化合物（rexinoid と呼 ばれることもある）も，レチノイン酸との見かけの 化学構造の差異が様々であっても, 広くレチノイド として扱われる。

レチノイン酸は生体内において, 細胞の増殖・分 化, 生体の恒常性維持, 形態形成に関わる重要な生 体内ホルモンである1,2)。現在, レチノイドには, 
急性前骨䯣球性白血病 APL の分化誘導療法剂とし てレチノイン酸（医薬一般名トレチノイン）が用い られるほか，その異性体や類似の活性を持つ合成化 合物が, 乾癬, 角化症, 重症のニキビなど, 皮膚の 炎症性・増殖性疾患の治療に用いられている1,3,4). レチノイン酸やその類似体を臨床的に用いた場合, 催奇形性の不安, 皮膚炎症状, 口唇炎, 血中脂質の 上昇等の副作用がしばしば問題にされ，その応用の 可能性を狭めているが，一方では，多くの合成レチ ノイドが新規に開発され，医薬としての性状を改善 する試みがなされている5)。そのような取り組みの 中で, 我々は合成レチノイド Am80（夕ミバロテ ン, 図 1）の開発を推進し, レチノイン酸治療後の APL 再発例に有効な医薬として, 最近, 医薬品と しての承認を得ることができた ${ }^{5,6)}$.

さて, 乾癬に対するレチノイドの効果は, 主に, 角化細胞の増殖, 分化に対する作用として説明され てきた。しかし, 現在では, 乾癬の発症に免疫細胞 の関与するところが大きいことが知られており，乾 癖等への治療効果を免疫機能に対するレチノイドの 効果としてとらえ直せば，レチノイドの医薬として の応用を他の免疫異常疾患に対しても広げられる. 本稿では，レチノイドの免疫系に対する作用に注目 し, 新規合成レチノイドの免疫疾患治療薬としての
可能性を論じてみたい.

\section{レチノイン酸と合成レチノイド}

まず，レチノイドの作用メカニズムをおさらいし てみたい.レチノイドの作用は, 細胞核内に存在す るレチノイン酸受容体 RAR $(\alpha, \beta, \gamma)$ に依存した ものである (図 2) ${ }^{1,2}$. ステロイドホルモン受容体 と同様, RAR はレチノイン酸との結合に依存して 活性化する転写因子である。また，RAR は，レチ ノイド X 受容体 RXR $(\alpha, \beta, \gamma)$ と呼ばれる別の核 内受容体とへテロ二量体を形成しており, 生体内で はRXR はレチノイン酸の 9-cis-異性体と結合した 時に活性化されると考えられる.レチノイン酸の広 範な生理作用は, それぞれに 3 種存在するサブタイ プ $\mathrm{RAR} \alpha, \beta, \gamma$ と $\mathrm{RXR} \alpha, \beta, \gamma$ の組織・時間特異的な 発現パターン, ヘテロ二量体の組み合わせ, 標的遺 伝子に対する選択性, 転写コファクターの使い分け により実現されていると考えられる. また, 組織内 のレチノイン酸濃度はレチノイン酸合成酵素 retinaldehyde dehydrogenase (RALDH) と代謝酵 素 Cyp26による絶妙な制御を受けており，また， 細胞内においてはレチノイン酸結合蛋白 (CRABP) の緩衝作用を通じてフリーのレチノイン酸の濃度が 調節されている $(\text { 図 } 2)^{7)}$.

\section{Natural Retinoic acid or mimics in Clinical Use}
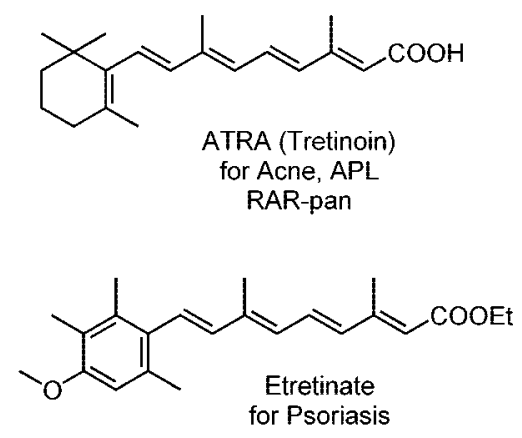

Synthetic Retinoid/Rexinod in Clinical Use

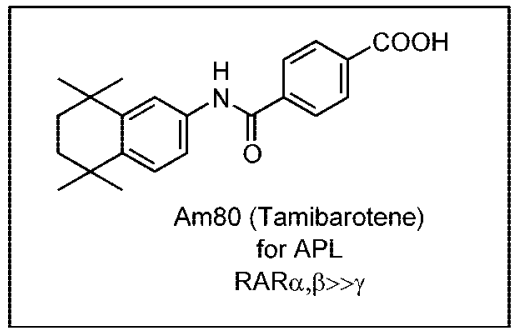

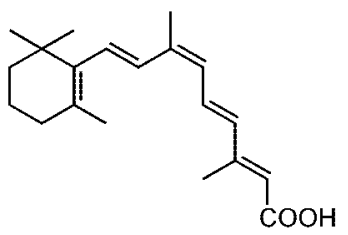

9-cis-RA (Alitretinoin) for Koposi sarcoma RAR,RXR-pan

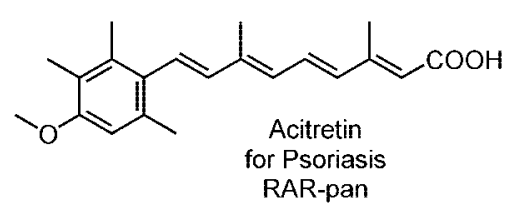

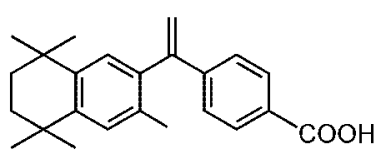

LGD 1069 (Targretin) for Cutaneous $T$ Iymphoma RXR-pan 
レチノイン酸を医薬として用いた場合，レチノイ ン酸には受容体サブクラスに対する選択性がほとん どないこと，脂溶性が高いことによって脂肪組織に 長時間留まること, 一方で, 短期間のうちに血中濃 度が低下することなどが，作用の選択性をなくし， 副作用の問題を大きくしている，従って，新規合成 レチノイドの開発においては，サブタイプ選択性と 良好な体内動態を有することが重要なポイントとな る.

\section{レチノイドの乾癬に対する治療効果}

レチノイドの作用における RAR サブタイプ選択 性の重要性は，皮膚での作用において見ることがで きる、レチノイン酸を皮膚に塗布した場合，基底膜 上の上皮細胞の著しい増殖とケラチノサイトの角化 への分化抑制が見られ，レチノイン酸の類似体 acitretin（図 1）を乾癬治療に用いた場合にも，同 様の上皮細胞増殖と角質層の脱落から皮膚の剥脱を 伴うことが多い.すなわち皮膚組織のターンオー バーが促進されることにより治療効果が発揮される
と理解しうるが，これは，患者の QOL を損なうと 共に, 皮膚透過性の克進による炎症症状の促進原因 にもなりうる.ノックアウトマウスを用いた研究か ら，レチノイン酸は， RAR $\gamma$ 活性化を通じてケラチ ノサイトからの HB-EGF 産生を誘導し, 基底上細 胞の増殖を促進することが示されている8 ${ }^{8}$. 一方,

$\operatorname{RAR} \alpha$ と $\beta$ に選択的で $\operatorname{RAR} \gamma$ は活性化しない合成 レチノイド Am80（タミバロテン）も乾癬の治療に おいてほぼステロイドと同等の効果を示すことが分 かっているが (図 3)9 ${ }^{9}$, Am80 では，表皮の落屑， すなわち皮膚のターンオーバーを著しく少なくして 皮膚組織の正常化を促すことができる(図 4) 10 12).

RAR $\gamma$ をほとんど活性化しない Am80 では, レチ ノイン酸に比べてケラチノサイトの HB-EGF 産生 誘導がわずかであり，そのような過剩な基底上細胞 の増殖が起きないのである。 それでも Am80 が乾 癄に対して十分な治療効果を示すことは, レチノイ ドが, RAR $\gamma$ に依存しない乾癬発症の本質的な部分 における正常化作用を発揮していることを示唆する.

乾癄は，ケラチノサイトの異常な増殖，分化を特

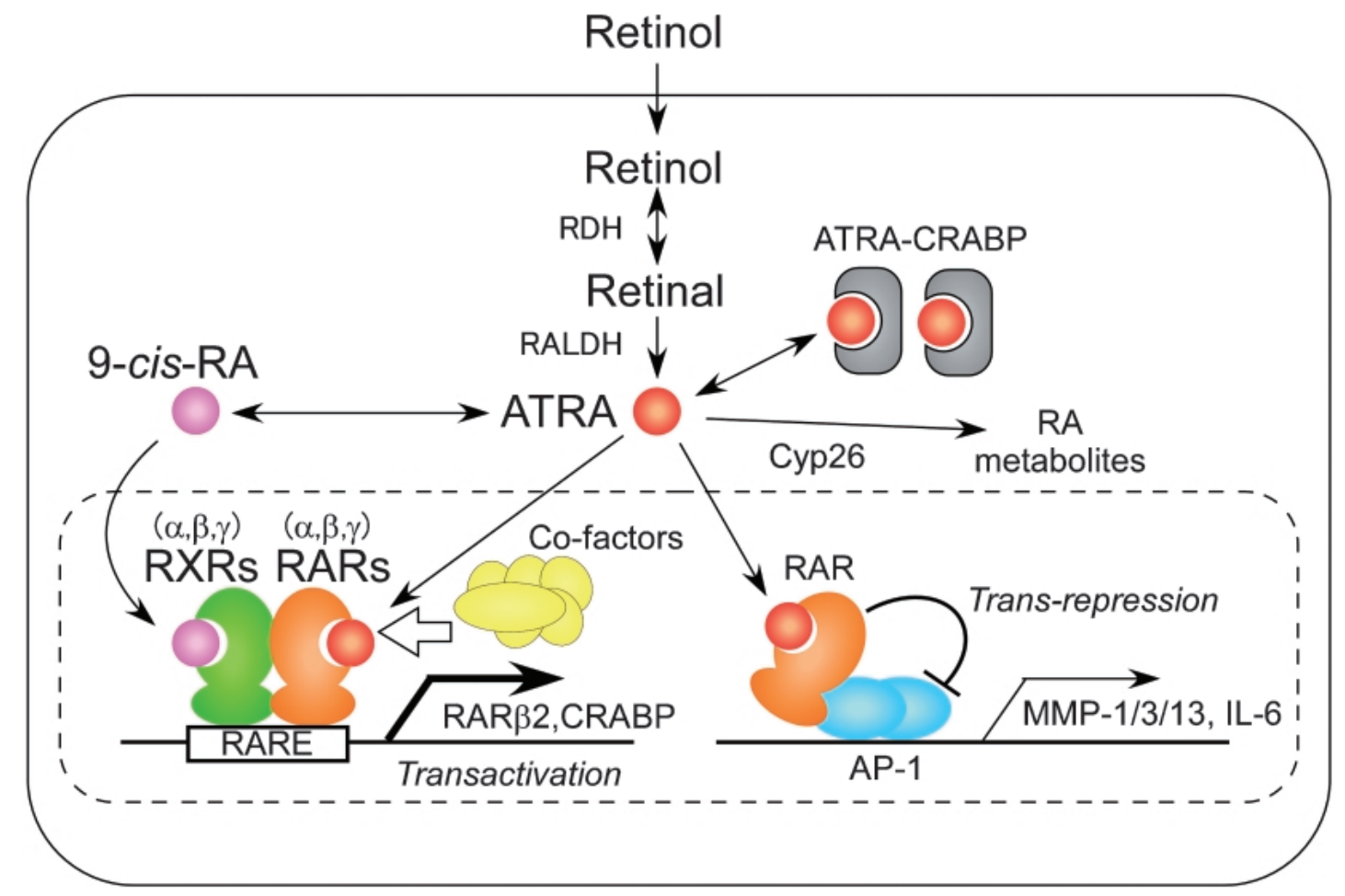

図 2 レチノイン酸シグナル

細胞に取り込まれたレチノールは, レチノール脱水素酵素（RDH） とレチナール脱水素酵素（RALDH）による2段階の酸化

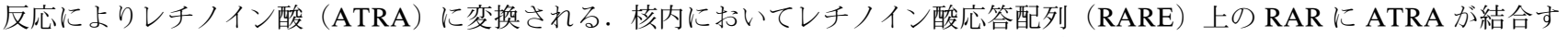
ると, 各種転写コファクターが RAR 上にリクルートされ, 下流標的遺伝子の転写を活性化する. RAR は, RXR とのへテロ二 量体として存在して抢り, ATRAの異性体 9-シスーレチノイン酸が RXR に結合すると, 相乗的な転写活性化が起こる（9シス体 はRARにも結合可能). RAR は，AP1 などの他の転写因子とクロストークすることにより，それらの転写活性を抑制すること もある. 細胞内のフリーATRA 濃度は, 細胞内レチノイン酸結合蛋白（CRABP）の緩衝作用により調節を受けると共に, Cyp26による代謝調節を受ける。図では, ATRA 合成・代謝, RAR 活性化をひとつの細胞内にまとめているが, これらはそれ ぞれ別々の細胞に起こりうる. 
徵とする皮膚疾患であり，その発症のメカニズムは 謎に包まれたままであるが，近年では，T 細胞によ り媒介される自己免疫的な疾患であると捉えられる ようになってきている13)。乾痽の疾患部位には CD4 抗原陽性または CD8 抗原陽性の $\mathrm{T}$ 細胞や樹状

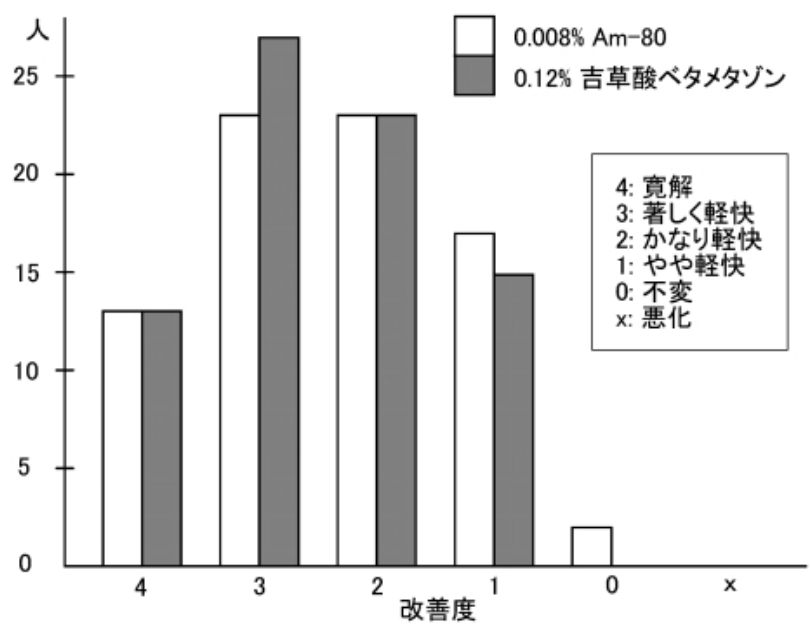

図 3 乾癄患者に抢ける $\mathrm{Am} 80$ 軟膏と吉草酸ベタメタゾン軟 膏の有効性の比較

吉草酸ベタメタゾン軟膏（リンデロン $(\mathrm{R})-\mathrm{V}$ 軟膏 $0.12 \%$ ) を対照薬とした Am-80 軟膏の第 III 相左右比較試験を行っ た. Am-80 軟膏の 1 日 1 回塗布による効果は吉草酸ベタメ タゾン軟膏より緩徐ではあるが有効な薬剤であることを示唆 するものであった゚.
細胞が見出され，それぞれ，インターフェロン $\gamma$ $(\mathrm{IFN}-\gamma)$ や TNF- $\alpha$ ，インターロイキン 12 (IL-12) や IL-23 等のサイトカインを産生し, 持続的な炎 症反応を担っていると考えられている. 次項で述べ るように，レチノイドには， $\mathrm{T}$ 細胞や樹状細胞に働 いて，エフェクター $\mathrm{T}$ 細胞の機能分化を制御する 作用があり，それによって乾癬の発症・病態を抑制 しうるものと考えられる.

さらに, 細胞内のシグナル伝達分子に目を向けれ ば， $\mathrm{NF} \kappa \mathrm{B}, \mathrm{AP}-1, \mathrm{STAT} 1, \mathrm{STAT} 3$ と言つた転写因 子の活性が乾癬の発症・病態に深く関与する事が示 唆されている14,15)。レチノイドの作用の本質が RAR を介した標的遺伝子の発現制御であることを 考えると, これらの転写因子との相互作用にも注目 したいところである. 我々が，レチノイドの研究を 始めて 20 年余が経つが，マウス皮膚発癌モデルで 典型的に示されるように, Protein kinase C (PKC) 及びその下流 AP-1 を活性化する発ガンプロモー ター phorbol 12-myristate 13-acetate（TPA）の作用 に対して，レチノイドは，阻害的に㗢くと認識して いる16). その要因の一つには, RAR と AP-1 の相 互作用によるものと思われるレチノイドの $\mathrm{AP}-1$ 活 性阻害を挙げることができるが (後述)， AP-1 フ

\section{症例 1}

\section{軟亳基材 3 週}

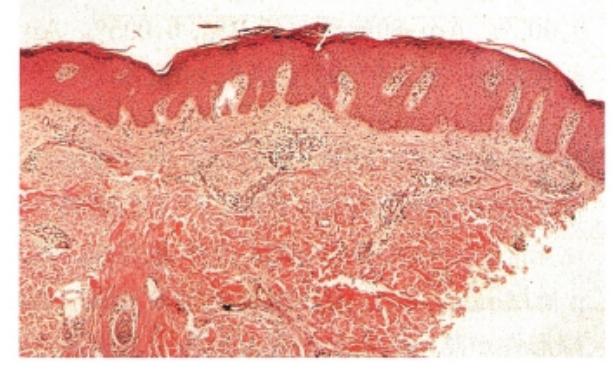

症例 2

処置前

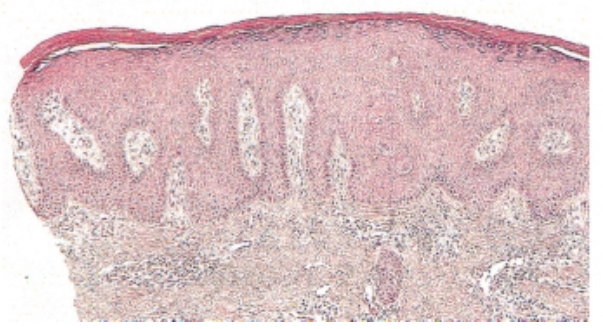

0. 008\% Am-80 軟膏 3 週

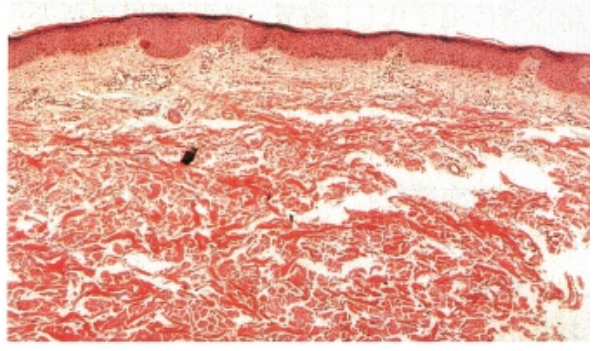

0. 008\% Am-80 軟膏 3 週

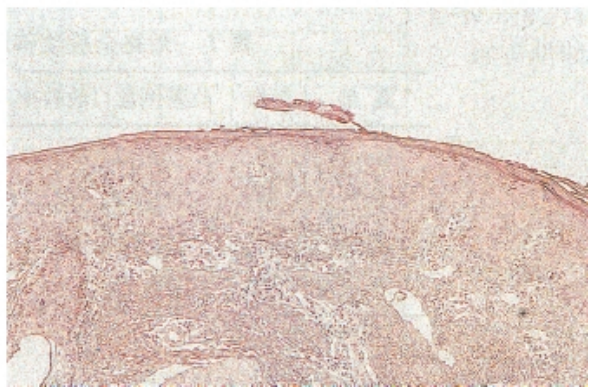

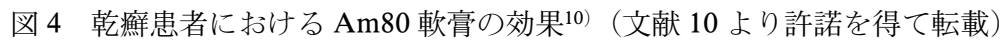


アミリー分子の一つJunB の働きにも注目したいと 考えている. 最近, JunB の発現が乾痽患者の疾患 部位表皮で低下していること，これに対応するよう に, JunB と AP-1 ファミリーの主要な一員である c-Jun の表皮特異的なダブルノックアウトマウスに おいて乾癄様の皮膚炎症と関節炎が誘導されること が報告されている17)。このモデルマウスにおいて T 細胞の関与は低いと報告されているものの, JunB は, $\mathrm{T}$ 細胞，顆粒球，ケラチノサイトの分化におい て，増殖促進的な c-Jun と拮抗する働きをすると 言われており, 加えて, エフェクター $\mathrm{T}$ 細胞分化 において Th2 分化促進的に働く18).レチノイドが 白血病細胞株 HL-60 細胞の増殖を抑えて顆粒球に 分化誘導すること, また, 次項に述べるようにレチ ノイドも Th2 促進的であることに注目すると,

RAR とJunB には, 作用としての関連性が認めら れ，両者の制御する遺伝子群に何らかの共通性や関 連性を見出すことも可能ではないかと考えられる.

\section{レチノイドによる T 細胞機能の制御}

獲得免疫系のエフェクター細胞として働くヘル パー T 細胞は, IFN- $\gamma$ を産生して細胞性免疫に主 に働くタイプ 1 ヘルパー $\mathrm{T}$ 細胞（Th1 細胞）と， IL-4 や IL-5 を産生して液性免疫に主に働くタイプ 2 ヘルパー $\mathrm{T}$ 細胞（Th2 細胞）とに分類され，互い に作用が拮抗する関係にある. 関節リウマチのよう な臟器特異性のある自己免疫疾患では, Th1/Th2 バランスが，Th1 側に病的に傾いた状態（Th1 ドミ ナント）であると考えられている．このような観点 からは, 乾痽も Th1 ドミナントな免疫異常疾患で あると捉えられる.

これまでの報告を見ると，レチノイドは，Th1/ Th2 の機能・分化に少なからず影響を与え, Th1 を 抑え，Th2 側にバランスを偏らせる傾向を示 す ${ }^{19,20)}$. 古くから知られるように，ビタミン A 欠 乏状態のヒトや動物は, 感染に対する防御力が著し く低下する。例えば，ビタミン A 欠乏ラットは成 長が停止した後, 感染により死亡するし, 途上国の 子ども達で感染による死亡リスクが高いことも，ビ タミン $\mathrm{A}$ 摂取の不足がその一因であると考えられ ている.このような感染に対する抵抗力の低下の原 因の一つを免疫グロブリン（Ig）産生能の低下に求 めることができる．正常なビタミン A レベルにあ るマウスの $\mathrm{B}$ 細胞をビタミン $\mathrm{A}$ 欠乏マウスの $\mathrm{T}$ 細 胞を用いて in vitroで抗原刺激した場合，誘導され
る IgG1 の産生量が低下するが，逆に，ビタミン A 欠乏マウスの B 細胞を正常なビタミン A レベルの マウスの $\mathrm{T}$ 細胞を用いて抗原刺激した場合には, IgG1 の産生量に抑制がかからない。従って, ビ夕 ミン $\mathrm{A}$ 欠乏マウスの免疫グロブリン減少は, $\mathrm{T}$ 細 胞機能の低下によるものであろうと理解される21). 一方, ビタミン $\mathrm{A}$ 高摂取状態のマウスにおいては, Th2 サイトカイン IL-4, IL-10 と IgA の産生上昇が 見られ，Th1 サイトカイン INF- $\gamma$ には産生抑制の 傾向が見られる22,23).

Th1, Th2 各サブセットは, 未梢での抗原提示を 受けたことのないナイーブ T 細胞が，樹状細胞を 代表とする抗原提示細胞からの刺激を受けて未梢リ ンパ組織において分化したものである. レチノイン 酸の抗原提示細胞への作用に注目すると, レチノイ ン酸で前処理した抗原提示細胞を用いた in vitro で の Th1/Th2 分化誘導の実験結果から, レチノイン 酸は, 抗原提示細胞に作用して IL-12 産生抑制を 介して Th1 誘導を抑制し, Th2 誘導を促進する事 がわかっている24,25)。さらに，ナイーブ $\mathrm{T}$ 細胞を 抗原提示細胞なしで in vitro で Th1/Th2 に分化誘 導する系を用いて， $\mathrm{T}$ 細胞に対するレチノイン酸の 直接的な影響を調べた岩田らの報告では，レチノイ ン酸および合成 RAR アゴニストは，Th1 誘導の抑 制と Th2 誘導の促進をもたらし，RAR アンタゴニ ストはこれを阻害した（図 5) ${ }^{20,26)}$ 。レチノイン酸 処理によって Th1 分化のマスター分子である T-bet の発現誘導が抑制され, Th2 分化に重要な c-maf の発現充進が見られたことから，レチノイン酸は, Th1/Th2 分化制御の本質的な部分に働いていると 考えられる。このように，レチノイドは，RARを 介して, 抗原提示細胞, ナイーブ $\mathrm{T}$ 細胞の両方に 作用し, Th1/Th2 分化のコントロールに関与す る. 加えて最近, RXRのリガンド結合部位にアミ ノ酸置換が起きているPinkie マウスにおいて, OVA 感作後の Th2 応答（IgG1 産生）が損なわれ, Th1 分化への偏りが見られる事も報告されてい る27)。これは, RXRの二量体パートナーである RAR やビタミン D 受容体のシグナル系に異常が出 ている結果と考えられる.

レチノイドによる免疫異常疾患の治療を考える場 合，以上のような Th1/Th2 分化制御作用から Th1 ドミナントな疾患により有効ではないかというコン セプトが立つ. 例えば, 多発性硬化症の動物モデル である実験的自己免疫性脳脊髄炎（EAE）は，典 


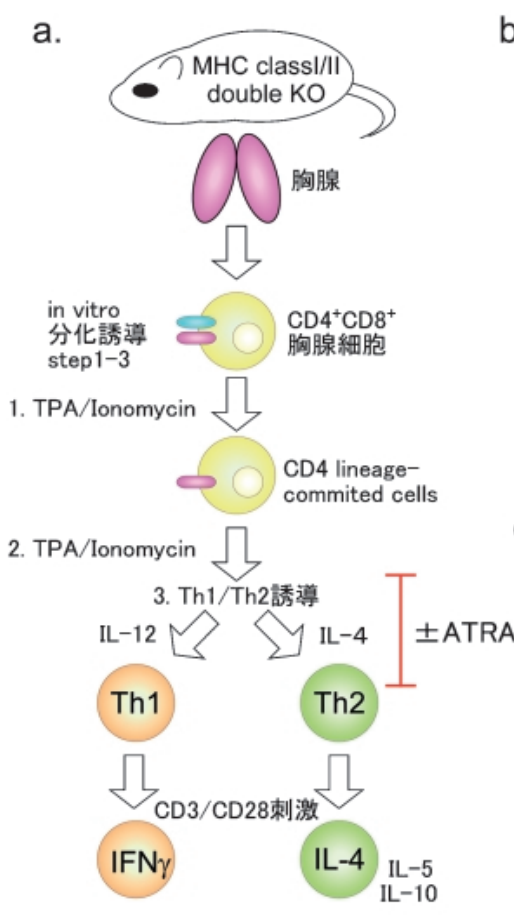

C.

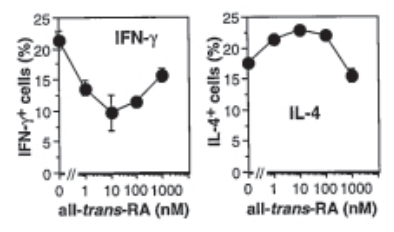

e.

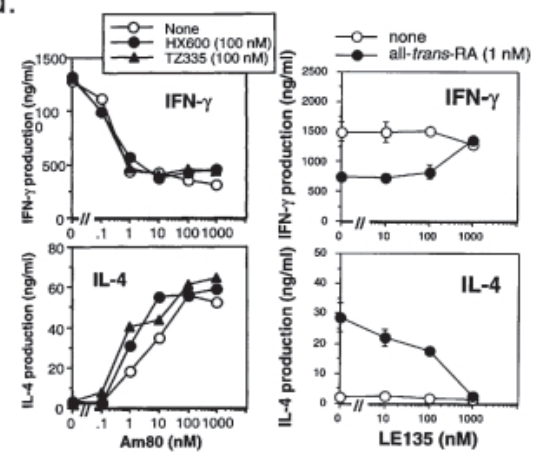

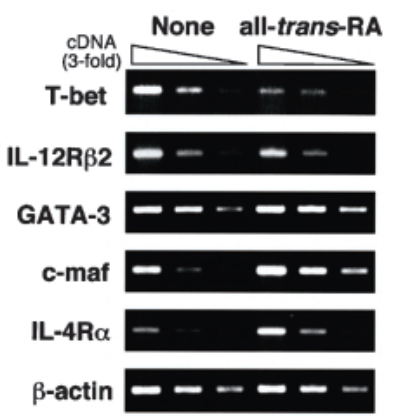

図 5 Th1/Th2 分化に対するレチノイドの作用26)

a)岩田らは, クラス I，クラス II の MHC 抗原を共に欠損するマウスから CD4 陽性ナイーブ T 細胞を調製し，レチノイン酸の 存在・非存在下, IL-12 と IL-4 を同時添加し, Th1 細胞, Th2 細胞の誘導を抗原提示細胞なしに in vitroでおこなった. CD3/ $\mathrm{CD} 28$ 刺激で産生されるサイトカインの量でレチノイン酸が Th1/Th2 分化に与える影響を評価した，b）レチノイン酸は，Th1 サ イトカインである IFN- $\gamma$ の産生を抑え, IL-4 などの Th2 サイトカインの産生を充進した. c) $10 \mathrm{nM}$ のレチノイン酸で，Th1 細 胞への分化が抑えられ, Th2 細胞への分化が促進された. d) 合成 RAR $\alpha / \beta$ アゴニスト Am80 は, レチノイン酸同様, IFN- $\gamma$ の産 生を抑え，IL-4 の産生を充進した。合成 RXR アゴニスト HX600, TZ235 の共存による相乗効果は見られない。また，RARアン タゴニスト LE135 は, ATRAの作用に拮抗した。これらの結果は, Th1/Th2 分化に対するレチノイドの作用が，もっぱら RAR を介していることを示す.e)レチノイン酸は, Th2 分化に関わる転写因子 c-maf の発現を促進し, Th1 分化の決定因子 t-bet の発 現を抑えた（RT-PCR）。(文献 26 より許諾を得て転載）

型的な Th1 ドミナントな自己免疫疾患モデルであ る. 従って, レチノイドは, EAE モデルに有効で あると予想されるが，実際，レチノイン酸や Am80 は, EAEの発症を抑制し，Am80 では EAE ラット 春髄中に見出される IFN- $\gamma$ の発現減少が認められ ている23,28,29). MBP 特異的なマウスリンパ節細胞 やヒト Th1 細胞株においては, レチノイン酸は $\mathrm{IL}-4$ 産生を誘導し, Th2 細胞様へと導く23,30)。近 年，IL-4 の全身投与が乾痽に対する治療法として 有効であるという報告がなされており，レチノイド による Th2 機能六進作用は, レチノイドの乾痽に 対する治療効果の分子的基盤の一つとなっていると 考えられる31)。さらに, RAR $\alpha$ 選択的アゴニスト ER-38925 では，アロの異所性心移植モデルの急性 拒絶反応を顕著に抑制するが，これはアロ抗原刺激 に対する IL-2, IL-12, INF- $\gamma$ の産生抑制に見られ る Th1 機能の抑制にその機序を求めることができ る ${ }^{32)}$ 。一方，全身性エリテマトーデス（SLE）のよ うな全身性の自己免疫疾患の病態では Th2 細胞の
影響が強いとされているが，SLEで見られる局所 的な臓器損傷に関しては, IFN- $\gamma$ 産生の Th1 細胞 の関与するところも大きいと考えられる，従って, ループス腎炎, 中枢神経障害, 呼吸器障害等の症状 が顕著なSLE の症例に関しても，レチノイドが有 効となりうるであろう。レチノイン酸が, SLEの モデルマウスにおいて腎臟障害を抑制することが報 告されており, また, 合成レチノイドでは $\operatorname{RAR} \alpha$ 選択的な E6060 が, NZB/W F1 マウスの腎障害を 抑え, 血中の IL-12, IgG2a のレベルを下げること が示されている33〜36).

\section{レチノイドの関節リウマチに対する効果 :}

\section{AP1 活性阻害と IL-6 シグナル阻害}

乾痽の他に, 以前からレチノイドの臨床応用が期 待されているもう一つの自己免疫性炎症疾患とし て, 関節リウマチを挙げることができる. 関節リウ マチの発症・病態にも Th1 応答が深く関与してく るため, その点からもレチノイドの効果を期待でき 
るのであるが，世の注目を集めるようになったきっ かけは, 関節リウマチ患者の滑膜細胞のコラゲナー ゼ（MMP-1）産生が, in vitro でレチノイン酸に より抑制される事を示した 1980 年の Brinkerhoff らの報告である37)。 その後, その作用メカニズム は，コラゲナーゼを含むメタロプロテアーゼ遺伝子 群（MMPs）の発現に重要な転写因子 AP-1 に対す る RAR の抑制作用（trans-repression）によると理 解されるようになった ${ }^{38)}$.レチノイン酸はコラーゲ ン誘発関節炎モデルにはあまり有効ではなかったも のの, etretinate と 4-HPR が, ラットのアジュバ ンド誘発関節炎モデルにおいてある程度の有効性が 示され，レチノイドの関節リウマチへの臨床応用に 期待が膨らんだ ${ }^{39,40)}$. だが，残念なことに，これら の化合物による臨床予備試験では，その有効性は 明らかにならなかった ${ }^{41,42)}$ 。前述の etretinate が 乾癄性関節炎には有効であることを考えると, etretinate は, リウマチ治療薬としては適当な特性 を持つ化合物ではなかつたのではないかという疑問 が残る。一方で，我々の実験では，Am80 はレチノ イン酸の効かないコラーゲン誘発関節炎モデルにお いても極めて有効であり，これまで試されたレチノ イドでは示されなかった関節リウマチへの有効性を 臨床的に示せるのではないかという期待が持てる.

(図 6) ${ }^{43,44)}$. 最近, RAR アンタゴニスト BMS189453 も, マウスのコラーゲン誘発関節炎モデル で有効性が報告された ${ }^{45,46)}$ 。この化合物は RAR を 活性化せずにAP1の抑制を示すレチノイドである が，炎症増強にかかわる $\mathrm{RAR} \gamma$ を阻害するアン夕 ゴニスト活性を持つため, それが関節炎に有効に働 いたと見ることも出来る.

関節リウマチに対するレチノイドの有効性を考え る場合，AP1 抑制を介した MMP 産生阻害に加え て注目される作用は，IL-6 産生およびそのシグナ ル伝達系に対する影響である，IL-6は，炎症時に 誘導される多面的作用を示すサイトカインであり, IL-6 の過剰産生は，関節リウマチにおいては，自 己反応性 $\mathrm{T}$ 細胞の活性化とアポトーシス阻害, 自 己抗体産生誘導, 破骨細胞活性化などのプロセスに 深く関わっていると考えられる47)，IL-6 は，マウ スのコラーゲン誘発関節炎の発症に必須な分子であ り, 臨床的にも抗 IL-6 受容体抗体投与による IL-6 シグナル遮断が，関節リウマチ治療に有効であるこ とが示されている48,49)．レチノイドはこの IL-6 産 生を非常に強く抑制する。レチノイン酸は, IL-1
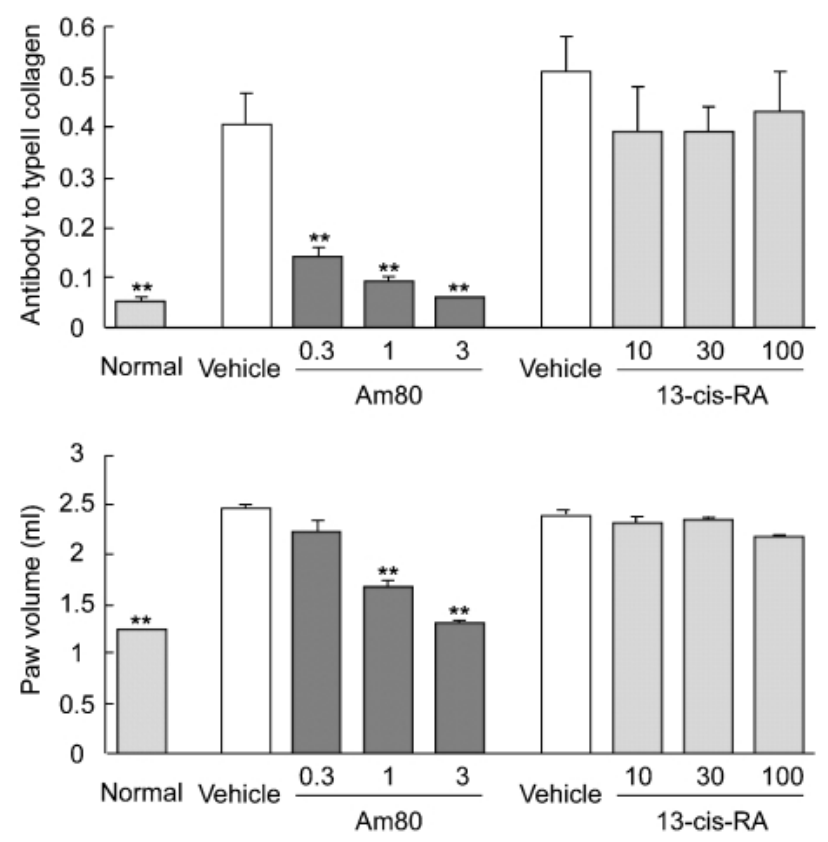

図 6 コラーゲン誘導関節炎モデルに拈けるAm80 と 13cisーレチノイン酸の効果の比較 ${ }^{44}$

ラットに typeII コラーゲンを皮内注射後, 1 日目から 23 日目末で表示の用量 $(\mathrm{mg} / \mathrm{kg} /$ day ) でAm80 と 13-cisーレチ ノイン酸を連日経口投与した。 24 日目の血中抗コラーゲン 抗体量（上）と Paw 容量（下）を測定した. **P $<0.01 （ v s$. vehicle)

刺激された肺線維芽細胞における IL-6 の産生誘導 を抑制し, 多発性骨髄腫細胞においては恒常的な IL-6 産生を抑制する ${ }^{50,51)}$. 合成レチノイド Am80 も骨芽細胞様細胞株 MG-63 細胞や MC3T3-E1 細 胞の IL-1 誘導 IL-6 産生を抑制し, LPS 投与マウ スやコラーゲン誘発関節炎においても, 血清 IL-6 濃度の上昇に対して抑制効果を示す44,52). 先に述べ た Am80 予防投与によるラット EAE の抑制におい ては, 脊髄 IL-6 mRNA 発現の増減が, INF- $\gamma$ 以 上に Am80 によく応答する ${ }^{28)}$. IL-6 遺伝子プロ モーター上には, 転写因子 $\mathrm{AP} 1, \mathrm{NF}-\kappa \mathrm{B}, \mathrm{C} / \mathrm{EBP}$ の認識配列の存在が明らかとなっており, レチノイ ドは, MMP の場合と同様, RAR とこれらの転写 因子とのクロストークを通じて IL-6 の産生を抑制 するものと考えられる ${ }^{53)}$. IL-6下流の細胞内シグ ナル伝達に目を向けると, IL-6 受容体 $\alpha$ 鎖と会合 して情報を細胞内に伝えるシグナル鎖 gp130 の発 現をレチノイン酸が抑制する効果もあることが, IL-6 を自己増殖因子とする多発性骨髄腫細胞にお いて報告されている ${ }^{51,54)}$ レチノイドは，Th1/Th2 バランス制御の作用に加えて, 炎症のメディエー ター分子である MMP と IL-6 の産生, 及び IL-6 のシグナル伝達分子 $\mathrm{gp} 130$ の発現を抑制すること により，関節リウマチに対する治療効果を示すとみ 
られる。

\section{レチノイドによるクローン病治療の可能性}

次に, 難治性炎症性腸疾患であるクローン病 (Crohn's disease) についても考察してみたい。ク ローン病は，若い成年に好発する慢性の炎症性腸疾 患であり，本邦でも登録患者数が 2 万人を超える難 治性の疾患である。クローン病の発症機序は，まだ 十分に明らかにされていないが，腸管における免疫 応答の異常が，その発症・病態に大きく関わってい ると考えられる55). クローン病も Th1 ドミナント とされる自己免疫疾患であり，また， IL-6がク ローン病の病態に深く関わっていることも明らかで ある ${ }^{47)}$. レチノイドによるクローン病の治療の可能 性も, 乾痽, リウマチ, 多発性硬化症の治療の可能 性という文脈から十分に考えられることである。

腸管は，その表面積から体内における最大の免疫 組織とも捉えられ，食物や常在細菌に対する免疫寛 容が常態として成立していることでも特徵的であ る56,57)。腸管では，本来的にエフェクター $\mathrm{T}$ 細胞 に対する抑制がかかっている。近年， $\mathrm{T}$ 細胞の新た なサブセット，制御性 $\mathrm{T}$ 細胞（レギュラトリー T 細胞）の存在が明らかとなり，これにはエフェク ター $\mathrm{T}$ 細胞の機能を抑制する働きがある ${ }^{58)}$. ク ローン病においては, 腸管組織の制御性 $\mathrm{T}$ 細胞の 機能低下によりエフェクター $\mathrm{T}$ 細胞の機能が充進 し，常在細菌等への免疫寛容が破綻することが，そ の発症・病態に重要ではないかと考えられるように なってきている。制御性 $\mathrm{T}$ 細胞は，エフェクター $\mathrm{T}$ 細胞の機能を抑制する $\mathrm{IL}-10$ や $\mathrm{TGF}-\beta$ の産生, 細胞接触を介してその作用を表し, TGF- $\beta$ ノック アウトマウスと IL-10 ノックアウトマウスは腸炎 を自然発症する。そこで興味深いことは，レチノイ ン酸には，以前から TGF- $\beta$ の産生を促進する作用 があることが知られていることで，ビタミン $\mathrm{A}$ 欠 そマウスにレチノイン酸を投与すると, 腸管粘膜に おいて TGF- $\beta 2, \mathrm{TGF}-\beta 3$ の発現が速やかに誘導さ れる59 61)。レチノイドには IgA 産生誘導する作用 があるが，腸管組織での $\mathrm{TGF}-\beta$ 産生促進を介して IgA へのクラススイッチを促進するのであろう。制 御性 T 細胞に対するレチノイドの影響を示した報 告はないが，腸管上皮組織には $\operatorname{RAR} \alpha, \gamma$ と共にレ チナール脱水素酵素 (RALDH) が高発現しており, これにより生合成されたレチノイン酸は, $\mathrm{TGF}-\beta$ の発現調節を介して腸管免疫の抑制的な環境の維持
に関わつているように思われる ${ }^{62 \sim 65)}$.

実のところ, クローン病とビタミン $\mathrm{A}$, すなわ ちレチノイドとの関係は, クローン病患者にビタミ ン A 血中濃度の低下が見られることから，1980 年 頃から少なからず注目を集めていた ${ }^{66,67)}$. ビタミン $\mathrm{A}$ の上皮組織を維持する作用から, 腸管において も粘膜上皮バリアの維持にビタミン A が重要と考 えられたのである. そこで, クローン病患者へのビ タミン A 補給が検討されれたが, 目立つた効果は 得られなかった ${ }^{68)}$. その後, 乾痽などの皮膚病治療 に合成レチノイド isotretinoin（13-cis-レチノイン 酸）や etretinateが，APL にレチノイン酸が用いら れるようになると, クローン病を併う症例もいくつ か報告されるようになったが，クローン病に対する 効果として積極的にレチノイドの有効性を確かにし た報告はない69 71)。しかし, 関節リウマチや乾癄 の場合と同様，クローン病治療に適した合成レチノ イドが存在する可能性は十分に残っている.

現在, 我々は, クローン病動物モデルでレチノイ ドの効果を調べており, ラット DNBS 誘発腸炎に おいて Am80 の治療効果を認めている（未発表デー 夕)。クローン病患者の腸管組織に浸潤する $\mathrm{T}$ 細 胞, マクロファージでは, STAT3のリン酸化, 活 性化が認められるが72 74)，我々の行った DNBS 誘 発腸炎モデルでも, 腸管組織抽出液中にSTAT3 の リン酸化六進を認め, Am80 投与群では抑制の傾向 を示した. STAT3 は T 細胞のアポトーシス阻害に 働くため, 抗炎症のための標的分子としての可能性 を有し, 今後も注目して解析を進めていきたいと考 えている75).

\section{免疫系におけるレチノイドの作用に関する新たな 展開}

最近の報告からレチノイドと免疫の関係に関する 興味深い知見を少し紹介したい。 まず， $\mathrm{T}$ 細胞の腸 管ホーミングにおいてレチノイン酸が重要な㗢きを していることを示した岩田らの報告が挙げられ る64). 彼らは, レチノイン酸処理によって T 細胞 の腸管へのホーミングに必要なケモカイン受容体 CCR9 の発現が誘導されることを見出し, 合成レチ ノイドも駆使して，その作用が RAR $\alpha$ 活性化を介 するものであることを示した. さらに, 消化管関連 リンパ系組織（GALT）において T 細胞に抗原提 示を行う樹状細胞が, 同時に RALDH を発現して レチノイン酸を産生し, $\mathrm{T}$ 細胞に CCR9 の発現を 
誘導していることを示した.レチノイン酸の新たな 生理的役割を分子レベルまで還元して明らかとした 画期的な発見である.クローン病治療へのレチノイ ドの応用を考えるにおいても重要な観察であるが, レチノイン酸による CCR9 発現誘導は, 生理的に 低いレベルの濃度で活性が飽和する，クローン病の 治療の観点からは, Th1/Th2 バランスに対して作 用する目的で与える薬理的な濃度のレチノイドの作 用とは状況が大きく異なると言えよう。

もう一つ，レチノイン酸の自然免疫系に対する作 用を示した報告を紹介すると，Liu らは，レチノイ ン酸がヒト単球に発現する病原体認識分子 Toll-like receptor 2（TLR2）の発現を抑制し, TRL2リガン ド刺激による IL-12, TNF- $\alpha, \mathrm{IL}-6$ の産生を抑制す ることを報告した ${ }^{76)}$ ．TLR2 を活性化する感染源の 一つにニキビ菌を挙げられるが，レチノイドの重症 ニキビに対する治療効果を考えると，彼らの報告に はなるほどと思える77)。 クローン病発症の外的要因 として細菌感染が関わっていることが指摘されてい るが, 単球・マクロファージに発現する腸内細菌リ
ポ多糖に対する細胞内受容体をコードする NOD2 遺伝子多型がクローン病患者に高頻度に認められる ことも近年見出された ${ }^{78,79)}$. 興味深いことに, NOD2 は，TRL2 シグナルの負の制御因子となりう ることが報告されており, クローン病では NOD2 の異常が TLR2 を介して Th1 応答を過剰にしてい る可能性が考えられる ${ }^{80)}$. TLR2 も, レチノイドに よるクローン病治療の可能性を考える時, 新たな治 療標的分子に入れて良いかもしれない.

\section{おわりに}

今考えれば，レチノイドが，正常な免疫系の維持 に必須であることはビタミン A の発見当初から明 らかであった。 レチノイドの免疫系に対する作用 は, 本稿で紹介したように, エフェクター $\mathrm{T}$ 細胞 に対する作用に始まって, 生理的, 薬理的に非常に 多岐にわたるものである (図 7)。自己免疫疾患の 発症・病態のメカニズムに関しては, 依然として不 明の部分が多いものの, 近年の免疫学の目覚しい発 展により，その詳細は次第に明らかになりつつあ

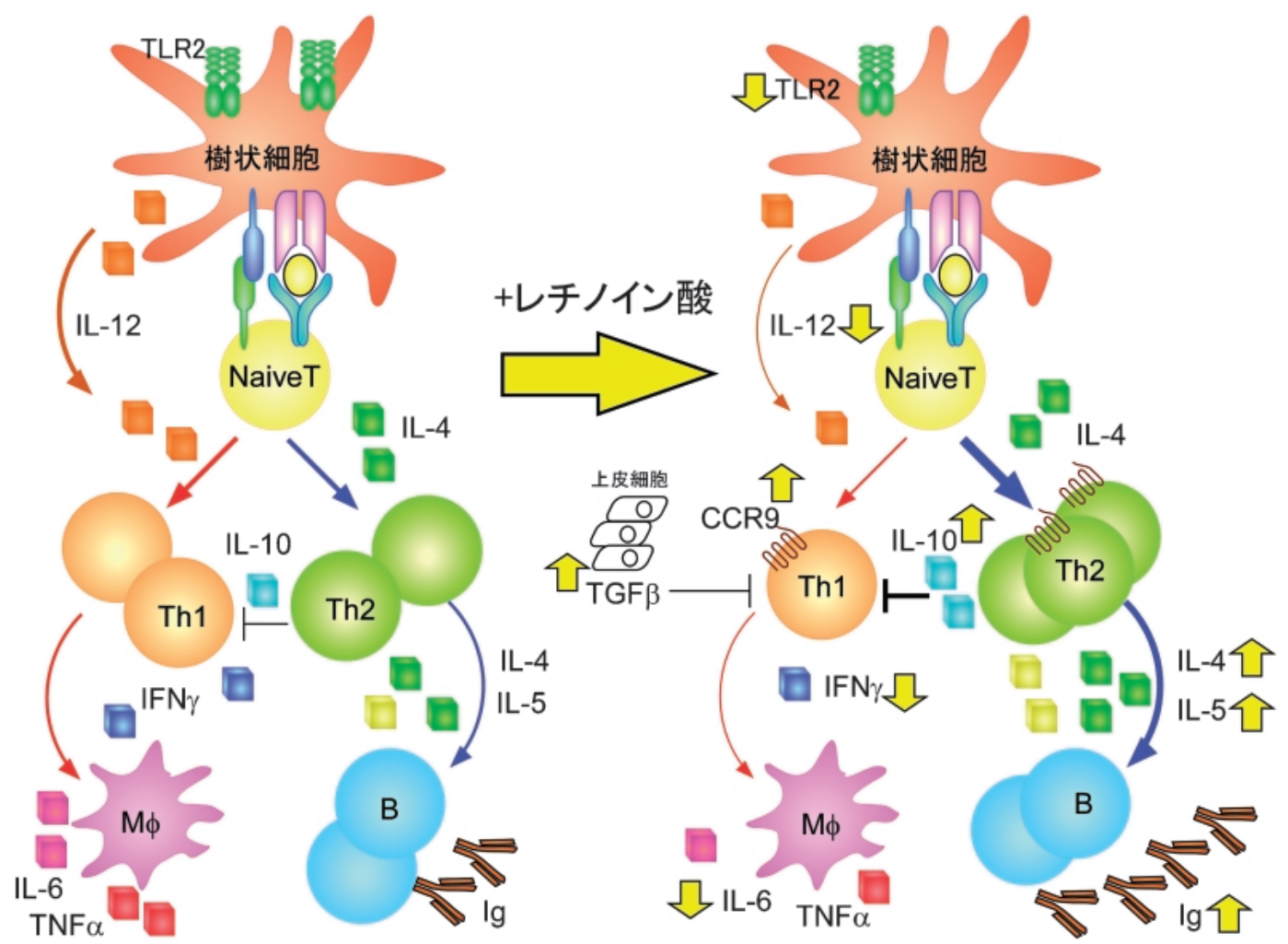

図 7 免疫応答に対するレチノイン酸の作用

レチノイン酸は, Th1 細胞分化を抑制し, Th2 細胞分化を促進し, 抗体産生の維持に働く.レチノイン酸は, Th 細胞の分化に 直接作用することに加え, 樹上細胞からの IL-12 産生を抑制する. マクロファージなどからの炎症性サイトカイン IL-6 産生は, $\operatorname{RAR}$ と C $/ \mathrm{EBP} \beta$ とのクロストークにより抑制されうる. 消化管関連リンパ系組織の樹上細胞は，自らレチノイン酸を産生し， Th 細胞に CCR9 の発現を誘導し, 腸管組織へのホーミングを促すことが知られている. 一方, レチノイン酸は TGF $\beta$ の産生を 誘導することも知られており, 特に腸管上皮で産生されるレチノイン酸は, 腸管組織の免疫抑制的な環境維持, $\operatorname{IgA}$ 産生の促進 に働いているのではないかと思われる. 
る．関連する臟器の違いや発症原因などにより，多 くの難治性の免疫疾患があるが，それぞれの疾患の 治療に適した特性を持つレチノイド化合物を選び出 すことが当面の課題である. レチノイドが多くの重 要な生命現象に関わっていることを考えると, 様々 な免疫異常の疾患にも基本的に共通のメカニズムが あり，その上でそれぞれのレチノイドが特徽的に働 く細胞や組織の環境があるのではなかろうかと考え ている.

レチノイド化合物の選択において留意すべき点 は, 合成レチノイドの効果は, 必ずしもレチノイン 酸の効果とは同一ではないことである．正常な免疫 系維持に必要と考えられるレチノイン酸の生理的濃 度は, 精々, 数 nM である. Th1/Th2 バランス制 御による正常な液性免疫の維持, $\mathrm{T}$ 細胞ホーミング を含む腸管免疫系の維持のような作用は, この生理 的濃度のレチノイン酸で十分であろう。さらに上の 薬理学的濃度のレチノイン酸では, Th1 分化抑制や AP1 抑制を介した炎症性サイトカイン, メディ エーターの産生に対する抑制作用が前面に出てくる と考えられ，より高濃度では全体として免疫抑制的 にも働きうるかもしれない。局時に，RAR $\gamma$ 選択 性の強いレチノイドでは, 主に RAR $\gamma$ 活性化を介 するであろう炎症惹起の側面も出てくる可能性があ る。レチノイン酸とは異なるサブタイプ選択性, 体 内動態などに特徴を与えられた合成レチノイドで は，それぞれの疾患に有利なレチノイン酸の作用を 選択的に示しうるのである。すすでに，様々な特性を 持った合成レチノイドが多数創製されている現在, 経口投与可能な新たな自己免疫疾患の治療薬がそこ に眠っている可能性を，自己免疫疾患の治療を目指 す多くの研究者の方々に是非知っていただきたいと 願う次第である.

\section{文献}

1) Sporn $\mathrm{MB}$, Roberts $\mathrm{AB}$, Goodman $\mathrm{DS}$, editors. : The Retinoids. $2^{\text {nd }}$ ed. New York, Raven Press. 1994.

2) Chambon P.: A decade of molecular biology of retinoic acid receptors. FASEB $J 10$ : 940954, 1996.

3) Altucci L, Gronenmeyer H.: The promise of retinoids to fight against cancer. Nature Rev Cancer 1 : 181-193, 2001.

4) Fisher GJ, Voorhess JJ. : Molecular mechanisms of retinoid actions in skin. FASEB $J \mathbf{1 0}$ :
1002-1013, 1996.

5) Kagechika H. : Novel synthetic retinoids and separation of the pleiotropic retinoidal activities. Curr Med Chem 9 : 591-608, 2002.

6) Shinjo K, et al. : Koseisho Leukemia Study Group. : Good prognosis of patients with acute promyelocytic leukemia who achieved second complete remission (CR) with a new retinoid, Am80, after relapse from CR induced by alltrans-retinoic acid. Int J Hematol 72 : 470-473, 2000.

7) Napoli JL. : Interactions of retinoid binding proteins and enzymes in retinoid metabolism. Biochim Biophys Acta 1440 : 139-162, 1999.

8) Chapellier B, et al. : Physiological and retinoidinduced proliferations of epidermis basal keratinocytes are differentialy controlled. EMBO J 21 : 3402-3413, 2002.

9) $\mathrm{Am}-80$ 軟膏臨床研究会 : $A m-80$ 軟膏の乾痽 に対する有効性の検討吉草酸ベタメタゾン軟 膏との左右比較試験 (第 3 相試験)。臨床医薬. $11: 733-746,1995$.

10) $A m-80$ 軟膏臨床研究会: $A m-80$ 軟膏第 2 相 - 用量設定予備試験. 臨床医薬. 11 : 545554, 1995.

11) Yoshimura K, et al. : Differential expression of heparin-binding EGF-like growth factor (HBEGF) mRNA in normal human keratinocytes induced by a variety of natural and synthetic retinoids. Exp Dermatol 12 (Suppl 2) : 28-34, 2003.

12）只木行啓, 田上八朗 : 4- $[(5,6,7,8$-tetrahydro-5, 5, 8, 8-tetramethyl-2-naphthalenyl)carbamoyl] benzoic acid 軟膏 (Am-80) の表 皮に与える影響. 皮膚科紀要. $88: 277-288$, 1993.

13) Bowcock AM, Krueger JG. : Getting under the skin : the immunogenetics of psoriasis. Nature Rev Immunol 5 : 699-711, 2005

14) Nickoloff BJ, Nestle FO. : Recent insights into the immunopathogenesis of psoriasis provide new therapeutic opportunities. J Clin Invest 113 : 1664-1675, 2004.

15) Sano $S$, et al. : Stat3 links activated keratinocytes and immunocytes required for development of psoriasis in a novel transgenic mouse model. Nature Med 11 : 43-49, 2005.

16) Verma AK, et al. : Inhibition of $12-\mathrm{O}^{-}$ tetradecanoylphorbol-13-acetate-induced ornithine decarboxylase activity in mouse epidermis by vitamin A analogs (retinoids). Cancer 
Res 38 : 793-801, 1978.

17) Zens R, et al. : Psoriasis-like skin disease and arthritis caused by inducible epidermal deletion of Jun proteins. Nature 437 : 369-375, 2005.

18) Hess J, Angel P, Schorpp-Kistner M. : AP-1 subunits : quarrel and harmony among siblings. J Cell Sci 117 : 5965-5973, 2004.

19) Hayes CE, et al. : Retinoids and Immunity. Nau H, Blaner WS. eds. "Retinoids The Biochemical and Molecular Basis of Vitamin A and Retinoid Action", (Handbook of Experimental Pharmacology, Vol. 139) : 589$610,1999$.

20）岩田 誠：レチノイン酸による Th1 分化の抑 制. 臨床免疫. $41: 520-526,2004$.

21) Carman JA, Smith SM, Hayes CE. : Characterization of a helper $\mathrm{T}$ lymphocyte defect in vitamin A-deficient mice. J Immunol 142 : 388393, 1989.

22) Cui D, Moldoveanu Z, Stephensen CB. : Highlevel dietary vitamin A enhances T-helper type 2 cytokine production and secretory immunoglobulin A response to influenza A virus infection in BALB/c mice. J Nutr 130 : 11321139, 2000.

23) Racke MK, et al. : Retinoid treatment of experimental allergic encephalomyelitis. IL-4 production correlates with improved disease course. J Immunol 154 : 450-458, 1995.

24) Hoag KA, et al. : Retinoic acid enhances the $T$ helper 2 cell development that is essential for robust antibody responses through its action on antigen-presenting cells. J Nutr 132:37363739, 2002.

25) Kang BY, et al. : Retinoid-mediated inhibition of interleukin-12 production in mouse macrophages suppresses Th1 cytokine profile in CD4 (+) T cells. Br J Pharmacol $130: 581-586$, 2000.

26) Iwata M, Eshima $Y$, Kagechika H. : Retinoic acids exert direct effects on $\mathrm{T}$ cells to suppress Th1 development and enhance Th2 development via retinoic acid receptors. Int Immunol 15 : 1017-1025, 2003.

27) $\mathrm{Du} X$, et al. : An essential role for Rxra in the development of Th2 responses. Eur J Immunol 35 : 3414-3423, 2005.

28) Wang $\mathrm{T}$, et al. : The effect of $\mathrm{Am}-80$, one of retinoids derivatives on experimental allergic encephalomyelitis in rats. Life Sci 67:18691879, 2000.
29) Massacesi L, et al. : Immunosuppressive activity of 13-cis-retinoic acid and prevention of experimental autoimmune encephalomyelitis in rats. J Clin Invest 88 : 1331-1337, 1991

30) Lovett-Racke AE, Racke MK. : Retinoic acid promotes the development of Th2-like human myelin basic protein-reactive T cells. Cell Immunol 215 : 54-60, 2002.

31) Ghoreschi K, et al. : Interleukin-4 therapy of psoriasis induces $\mathrm{Th} 2$ responses and improves human autoimmune disease. Nature Med 9: 40-46, 2003.

32) Seino K, et al. : Prevention of acute and chronic allograft rejection by a novel retinoic acid receptor-alpha-selective agonist. Int Immunol 16 : 665-673, 2004.

33) Nozaki Y, et al. : The beneficial effects of treatment with all-trans-retinoic acid pluscorticosteroid on autoimmune nephritis in NZB/ WF mice. Clin Exp Immunol 139 : 74-83, 2005.

34) Kinoshita K, et al. : Retinoic acid reduces autoimmune renal injury and increases survival in NZB/W F1 mice. J Immunol 170 : 5793-5798, 2003.

35) Perez de Lema G, et al. : Retinoic acid treatment protects MRL/lpr lupus mice from the development of glomerular disease. Kidney Int 66 : 1018-1028, 2004.

36) Yamauchi $T$, et al. : Effect of E6060, a novel subtype-selective retinoid, on lupus-like nephritis in female (NZBxNZW)F1 mice. J Pharmacol Exp Ther 312 : 938-944, 2005.

37) Brinkerhoff $\mathrm{CE}$, et al. : Inhibition by retinoic acid of collagenase production by rheumatoid synovial cells. $N$ Eng J Med 303 : 432-435, 1980.

38) Nicolson R, et al. : Negative regulation of the rat stromelysin gene promoter by retinoic acid is mediated by an $\mathrm{AP}-1$ binding site. EMBO J 9 : 4443-4454, 1990.

39) Brinckerhoff CE, Coffey JW, Sullivan AC. : 13-cis-retinoic acid decreases inflammation and collagenase production in rats with adjuvant arthritis. Science 221 : 756-758, 1983.

40) Trentham DE, Brinckerhoff CE. : Augmentation of collagen arthritis by synthetic analogues of retinoic acid. J Immunol 129 : 2668-2672, 1982.

41) Bird HA, et al. : A clinical and biochemical evaluation of etretinate in rheumatoid arthritis. Rheumatol Int 8 : 55-59, 1988. 
42) Gravallese EM, et al. : N-[4-hydroxyphenyl] retinamide in rheumatoid arthritis: a pilot study. Arthritis Rheum 39 : 1021-1026, 1996.

43) Kuwabara K, Shudo K, Hori Y. : Novel synthetic retinoic acid inhibits rat collagen arthritis and differentially affects serum immunoglobulin subclass levels. FEBS Lett 378 : 153-156, 1996.

44) Nagai H, et al. : Effect of Am-80, a synthetic derivative of retinoid, on experimental Arthritis in Mice. Pharmacology 58 : 101-112, 1999.

45) Beehler BC, et al. : Inhibition of disease progression by a novel retinoid antagonist in animal models of arthritis. $J$ Rheumatol 30 : 355-363, 2003.

46) Brinckerhoff CE, Sporn MB. : Retinoids and rexinoids for the 21 st century: a brave new world for arthritis. $J$ Rheumatol $30: 211-213$, 2003.

47) Nishimoto N, Kishimoto T. : Inhibition of IL-6 for the treatment of inflammatory diseases. Curr Opin Pharmacol 4 : 386-391, 2004.

48) Alonzi $T$, et al. : Interleukin 6 is required for the development of collagen-induced arthritis. J Exp Med 187 : 461-468, 1998.

49) Nishimoto $N$, et al. : Treatment of rheumatoid arthritis with humanized anti-interleukin-6 receptor antibody : a multicenter, double-blind, placebo-controlled trial. Arthritis Rheum 50: 1761-1769, 2004.

50) Zitnik RJ, et al. : Retinoic acid inhibition of IL-1-induced IL- 6 production by human lung fibroblasts. J Immunol 152 : 1419-1427, 1994.

51) Ogata $A$, et al. : Inhibitory effect of all-trans retinoic acid on the growth of freshly isolated myeloma cells via interference with interleukin6 signal transduction. Blood $84: 3040-3046$, 1994.

52) Kagechika $\mathrm{H}$, et al. : Inhibition of IL-1-induced IL-6 production by synthetic retinoids. Biochem Biophys Res Commun 231 : 243-248, 1997.

53) Nagpal S, et al. : Retinoid antagonism of NFIL6 : insight into the mechanism of antiproliferative effects of retinoids in Kaposi's sarcoma. Mol Cell Biol 17 : 4159-4168, 1997.

54) Sidell N, et al. : Retinoic acid-induced growth inhibition of a human myeloma cell line via down-regulation of IL-6 receptors. J Immunol 146 : 3809-3814, 1991.

55) Shanahan F.: Crohn's disease. Lancet 359 : 62-69, 2002.
56) Monteleone I, et al. : Immunoregulation in the gut : success and failures in human disease. Gut 50 (Suppl 3) : iii60-64, 2002.

57) Macdonald TT, Monteleone G. : Immunity, inflammation, and allergy in the gut. Science 307 : 1920-1925, 2005.

58) Maloy KJ, Powrie F. : Regulatory T cells in the control of immune pathology. Nat Immunol 2 : 816-822, 2001.

59) Glick AB, et al. : Retinoic acid induces transforming growth factor-beta 2 in cultured keratinocytes and mouse epidermis. Cell Regul 1 : 87-97, 1989.

60) Han GR, et al. : All-trans-retinoic acid increases transforming growth factor-beta2 and insulin-like growth factor binding protein-3 expression through a retinoic acid receptor-alphadependent signaling pathway. J Biol Chem 272 : 13711-13716, 1997.

61) Glick AB, et al. : Complex regulation of TGF beta expression by retinoic acid in the vitamin A-deficient rat. Development 111 : 1081-1086, 1991.

62) Plateroti $M$, et al. : Mesenchyme-mediated effects of retinoic acid during rat intestinal development. J Cell Sci 110 : 1227-1238, 1997.

63) Niederreither $K$, et al. : Differential expression of retinoic acid-synthesizing (RALDH) enzymes during fetal development and organ differentiation in the mouse. Mech Dev 110 : 165-171, 2002.

64) Iwata $M$, et al. : Retinoic acid imprints guthoming specificity on $\mathrm{T}$ cells. Immunity 21 : 527-538, 2004.

65) Monteleone G, et al. : Blocking Smad7 restores TGF-beta1 signaling in chronic inflammatory bowel disease. J Clin Invest 108: 601-609, 2001.

66) Main AN, et al. : Vitamin A deficiency in Crohn's disease. Gut 24 : 1169-1175, 1983.

67) Dvorak AM. : Vitamin A in Crohn's disease. Lancet 1 (8181) : 1303-1304, 1980.

68) Wright JP, et al. : Vitamin A therapy in patients with Crohn's disease. Gastroenterology 88 : 512-514, 1985.

69) Gold MH, Roenigk HH Jr., Vanagunas A.: The retinoids and inflammatory bowel disease. Arch Dermatol 124 : 325-326, 1988.

70) Godfrey KM, James MP. : Treatment of severe acne with isotretinoin in patients with inflammatory bowel disease. Br J Dermatol 123 : 653- 
$655,1990$.

71) Harewood G, Markovic S. : Treatment of acute myeloid leukemia M3 in a patient with Crohn's disease. Cancer Invest 18 : 98, 2000.

72) Lovato P, et al. : Constitutive STAT3 activation in intestinal $\mathrm{T}$ cells from patients with Crohn's disease. J Biol Chem 278: 1677716781, 2003.

73) Mudter J, et al. : Activation Pattern of signal trancducers and activators of transcription (STAT) factors in inflammatory bowel disease. Am J Gastroenterol 100 : 64-72, 2005.

74) Musso A, et al. : Signal transducers and activators of transcription 3 signaling pathway-An essential mediator of inflammatory bowel disease and other forms of intestinal inflammation. Inflamm Bowel Dis 11 : 91-98, 2005.

75) Akira S. : Roles of STAT3 defined by tissue- specific gene targeting. Oncogene 19:26072611, 2000.

76) Liu PT, et al. : All-trans retinoic acid downregulates TLR2 expression and function. J Immunol 174 : 2467-2470, 2005.

77) Kim J, et al. : Activation of toll-like receptor 2 in acne triggers inflammatory cytokine responses. J Immunol 169 : 1535-1541, 2002.

78) Hugot JP, et al. : Association of NOD2 leucinerich repeat variants with susceptibility to Crohn's disease. Nature 411 : 599-603, 2001.

79) Ogura Y, et al. : A frameshift mutation in NOD2 associated with susceptibility to Crohn's disease. Nature 411 : 603-606, 2001.

80) Watanabe T, et al. : NOD2 is a negative regulator of Toll-like receptor 2 -mediated $\mathrm{T}$ helper type 1 responses. Nature Immunol 5 : 800-808, 2004. 